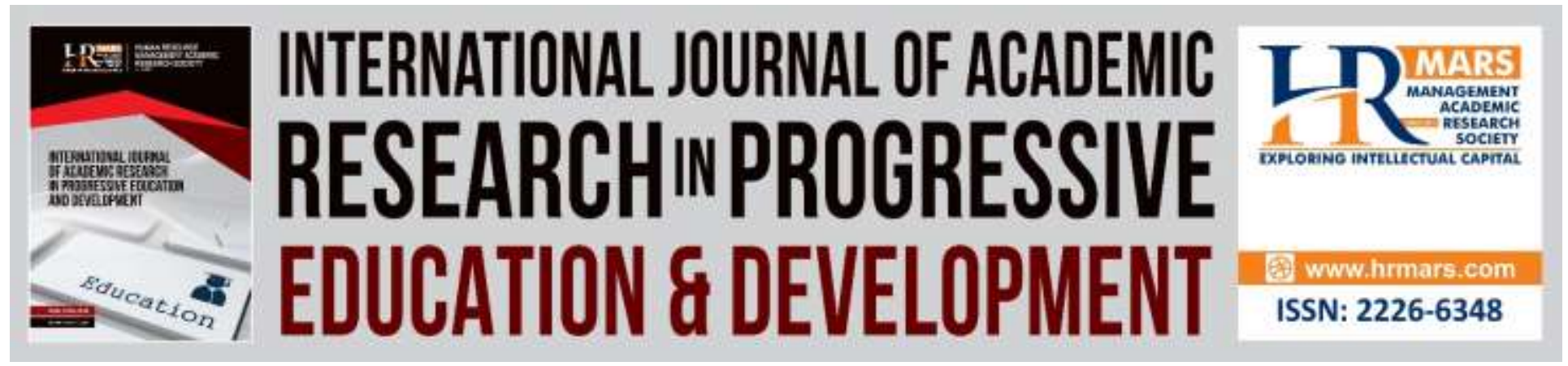

\title{
Involvement of The Communist Era in 13 Mei 1969 Racial Riot
}

Mohamad Asrol Arpidi Mamat, Ishak Saat, Ahmad Zainudin Husin, Ruhaizan Sulaiman

To Link this Article: http://dx.doi.org/10.6007/IJARPED/v9-i2/7229

DOI:10.6007/IJARPED/v9-i2/7229

Received: 10 February 2020, Revised: 14 March 2020, Accepted: 30 March 2020

Published Online: 13 April 2020

In-Text Citation: (Mamat et al., 2020)

To Cite this Article: Mamat, M. A. A., Saat, I., Husin, A. Z., \& Sulaiman, R. (2020). Involvement of The Communist Era in 13 Mei 1969 Racial Riot. International Journal of Academic Research in Progressive Education And Development, 9(2), 69-80.

Copyright: (C) 2020 The Author(s)

Published by Human Resource Management Academic Research Society (www.hrmars.com)

This article is published under the Creative Commons Attribution (CC BY 4.0) license. Anyone may reproduce, distribute, translate and create derivative works of this article (for both commercial and non-commercial purposes), subject to full attribution to the original publication and authors. The full terms of this license may be seen

at: $\underline{\text { http://creativecommons.org/licences/by/4.0/legalcode }}$

\section{Vol. 9 (2) 2020, Pg. 69 - 80}

Full Terms \& Conditions of access and use can be found at http://hrmars.com/index.php/pages/detail/publication-ethics 


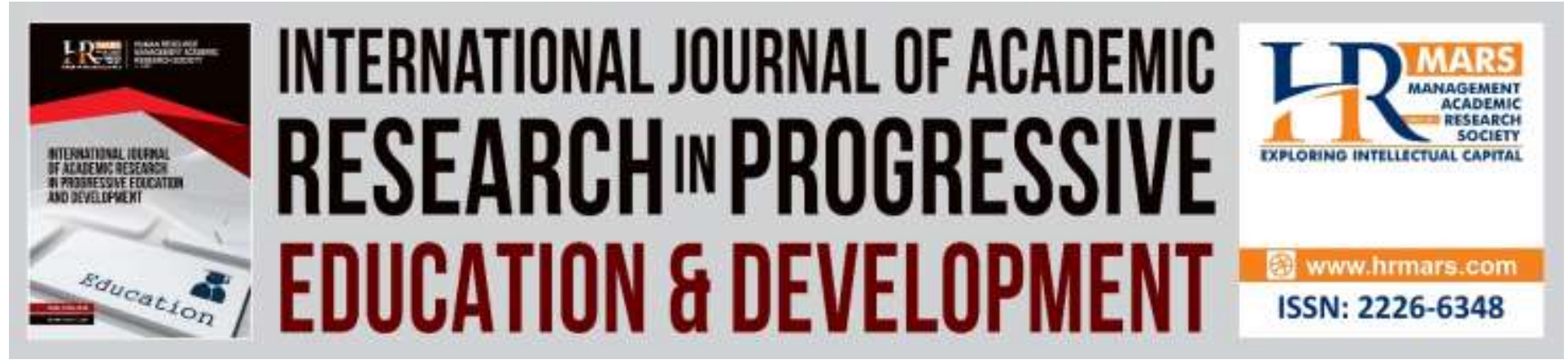

\title{
Involvement of The Communist Era in 13 Mei 1969 Racial Riot
}

\section{Mohamad Asrol Arpidi Mamat, Ishak Saat, Ahmad Zainudin Husin} Department of History, Faculty of Humanities, Sultan Idris Education University, 35900 Tanjung Malim, Perak.

Email: r_pd85@yahoo.com, ishakhj@fsk.upsi.edu.my, zainuddin.husin @fsk.upsi.edu.my

\section{Ruhaizan Sulaiman}

Centre for Fundamental Studies, Universiti Sultan Zainal Abidin (UniSZA), 21300, Kuala Nerus,

Terengganu

Email: ruhaizan@unisza.edu.my

\begin{abstract}
This article is intended to point out the involvement of the communist era during race riots that occurred on May 13, 1969. Majority of us Malaysians are not so exposed to the involvement of the communist and their agenda to create chaos and unrest in this country. The communists using racial incitement and influencing the public through the Labor Party and Left-wing Parties. This study was conducted primarily using qualitative methods and subjective chronology. The information obtained was taken and analyzed in the form of primary and secondary sources. Primary sources are composed of the Government White Paper, Command Paper, Hansard House of Commons, Leader's speeches, thesis, interviews, Majlis gerakan Negara (MAGERAN) reports, the Federal Budget Reports and documents of the Federal Constitution. While secondary sources are made up of scientific journals, books and reference information obtained from websites. The results portrait that there are a series of very clear involvement of the communist party before, during and after the riots until the 1970s. The focus of the communists is to create an atmosphere of chaos and tension between them which would indirectly weaken the national defense system. The government through the implementation of the administration under MAGERAN managed to curb the activities of communist control and stop the riots. Later the government took drastic measures, particularly to reduce the level difference between the racial and economic disparities by intensifying security measures in order to break the communist elements in the country.
\end{abstract}

Keywords: Malayan Communist Party (Communist), May 13, 1969 Riot, Majlis Gerakan Negara (MAGERAN), Security Forces, Tun Abdul Razak. 


\section{Introduction}

The May 13, 1969 racial riot is basically the result of provocation against the Chinese community towards the Malays which involving the encroachment on Article 152 and 153 of the Constitution which demanding the equality between Malays and non-Malays, claims against the establishment of University Merdeka, Chinese language and culture, and provocatively declared that the Malays are not the Bumiputera in this country when compared to other races. The communists also set plans to create chaos and cause chaos by inciting people to boycott the 1969 general election (Command Paper 14, 1988: 16). The communists carry out his agenda through the components of the opposition Democratic Action Party (DAP), Parti Gerakan Rakyat Malaysia (Gerakan) and the Labor Party.

In the event of riots, the communist seen to also play an active role behind these riots. They were using Chinese and the Chinese parties to implement the agenda. When we view racial riots on May 13,1969, most of us only imagine the conflict between the Malays, Chinese, Indians and also a number of other races living in the country. However, the communist party rather use a variety of cunning tactics to create unrest and chaos in the country. During the Japanese colonization, racism intensified. Japanese government created policy of which oppressing the Chinese while the Malays were given good service. Japan's government Discrimination resulting in feelings of irritation by the Chinese towards the Malays. Such things can be clearly demonstrated through violence for 14 days by the Malayan Peoples Anti-Japanese Army (MPAJA). Many Malays victims killed, tortured and exposed to other atrocities. When the Malays react, it led to a battle between the Malays and the Chinese who cause loss of lives and properties on both sides (Zahar, 2013).

Communist Party of Malaya (CPM) continues to exploit all the issues that arise in order to advance its objective to seize power and establish a communist state. PKM organized propaganda and indirect measures towards each of the Chinese, Malays and Indians to exploit the discontent experienced by people who are considered relevant (Command Paper 14, 1988: 16). Communist ideology spreading in Malaya originated from China. Chinese laborers brought this ideology among the Chinese community in Malaya. Communists in Malaya operated under the control of the Communist Party of Nanyang (South Seas Communist Party) which controls the two organizations in Malaya namely the General Trade Union of Nanyang (Nanyang General Labor Union) and the Communist Youth League. Both of these organizations banned by the government in 1926 as a demonstration. The Malayan Communist leaders later formed the Communist Party of Malaya (CPM) on April 30, 1930.

\section{Issues Studied}

The study of the involvement of the communist era during the race riots on May 13, 1969 is a continuation in order to further inspire more academic studies about this issue. This study shows the involvement of communists in the race riots that occurred on May 13, 1969. Majority of us believe that the communists also plays a very important role in order to create chaos in the country. Particularly during the upheaval in the country is when the communists tried their hardest to create chaos in order to seize the reins of state government. As such, the key issue for 
Vol. 9, No. 2, 2020, E-ISSN: 2226-6348 C 2020 HRMARS

this study is whether the communist elements exist at the time of the event May 13, 1969 racial riots and and to identify the extent of their involvement during the riots.

\section{Review and Discussion}

Based on the research analysis, some findings have been identified as the foundation of the framework and content of the study. In this part of the data analysis was performed for analyzing and discussing the overall scope of the study. The findings of the study analysis and discussion are as follows.

\section{Before Riots May 13, 1969}

The communist ideology brought to this country by the representative of the Communist Party of China, who sets up an organization called the Communist Party (South Seas), in 1928. Two years later the party was changed to a separate Communist Party of Malaya (CPM) to prepare for the establishment of a 'Communist Country' in Malaya. In 1948, the Communist Party of Malaya (CPM) which at that time not yet banned in Malaya, launched an armed insurrection as a means of struggle. They also carry out movements such as threaten, kill, robbery and committed abuses against the local population (Government White Paper, 1959: 18-19). Furthermore, during the state of emergency (darurat), racism become more prominent. Communist Party of Malaya (CPM) continue to fight against the British and the British had to spent a lot of resources to resist PKM. Naturally suspicion among race has long existed. Racism is an effort to recognize that some people are better than other people and try to try to push the other from sharing either power or rights of other races. In order to become a folk hero of racism here's a chance to take place. Salvos between the races take place in all aspects of safeguarding the interests of each community involving social, economic and political (Zahar, 2013).

During the 1950s era, the educational system is closely associated with security because martial law was still in effect and some Chinese secondary schools are still the focus of a disturbance. While serving in the Ministry of Home Affairs, Tun Abdul Razak was directly involved in efforts to end the state of emergency to combat the communist country. In 1955 the Communist Party of Malaya (CPM) has a new position. The party making the claim that their armed retaliation is helping the struggle for the independence of Malaya. This way allows them the freedom to quickly expand its influence and to undermine the government's plans. Such are the tricks communists use in the freedom plan in 1955 (Government White Paper, 1959: 2021). Soon after the meeting between Tunku Abdul Rahman and Chin Peng in Baling, the party states their intention of continuing endeavors to get the terms "freedom" but the government aware of the tricks behind this plan. The government is not willing to compromise the safety of the newly independent country to recognize the Communist Party of Malaya (CPM) as if they were doing so means that the government provide the opportunity for the communists to achieve their goal (Omar, 2005/2006:82). Before the country's independence, Malayan Peoples Anti-Japanese Army (MPAJA) that most of its members are made up of the Chinese trying to gain control the Malay states, while the Communist Party of Malaya (CPM) launched a guerrilla war against the British (Jamaludin, 2011:45 ). 
By 1960, all of the Malay Peninsula into 'Kawasan Putih' and the Emergency Law in force since 1948 is repealed. Upon completion of the communist threat, the government then turned his attention to the development of the country and rural areas and working to raise the living standards of people in rural areas by using a structured and organized manner. After independence was achieved, riots were occuring in Bukit Mertajam in 1964, Kuala Lumpur and Penang in 1965 and 1967 respectively. On 9 May 1969 the Labor Party supporters who are affected by the Malayan Communist Party (MCP) held a funeral procession Lim Soon Seng, a supporter Labor Party who was shot dead for trying to act wild and dangerous to the security forces. The procession which started as a regular procession, then turns to an uncontrollable protests. This action is planned by communist party aimed to create chaos in the country and overthrow the government to establish a communist state. Furthermore, after the announcement of election results, DAP and Gerakan faking a 'victory' parade in Kuala Lumpur on 11 and 12 May 1969. Some of the procession was organized illegally without obtaining a permit from the police. The parade is held in an uncontrollable situation and invited to race riots.

Tunku Abdul Rahman (Tunku) had his share of communist threat until the outbreak of a state of emergency in Malaya, Indonesian confrontation orchestrated by the Indonesian Communist Party (PKI) and the support given by China to the communists in Malaya is among the few events that affect his personality to hate communists (Faith, 1964). Tunku Abdul Rahman said that "We must realize that the Chinese Communist all the time staring at us with hope that one day will rule the whole of Southeast Asia" (Speech of Tunku Abdul Rahman, 31 July 1966). Next Tunku also admitted; "It's true I'm afraid the Chinese Communists and their ideologies. If they do not cause aggression directly they will use others to cause chaos" (New Straits Times, 1968). Clearly, the race riots that occurred on May 13, 1969 is the provocation of the Chinese and the agenda planned by the communists.

\section{During Riots May 13, 1969}

Tun Abdul Razak, the Deputy Prime Minister also acknowledged the involvement of communists in race riots in 1969 through his speech that:

"We in Malaysia are still facing threats from the communist terrorists who carry out their evil doings not only in borders but even infiltrate the residential areas lately. They run dark conspiracy campaigns and propaganda among our multiracial community, while looking for every opportunity to destroy the unity ... Because the more damage to the our relationship and race relations, they more easily be able to achieve their evil schemes and seize power in the country "(Speech by the Prime Minister, 1st July, 1971: 239)."

Tun Abdul Razak pointed out that during the May 13 racial riots, the country still faces the threat of communist factions that are active in spreading their propaganda, especially in the settlements. The main focus is to undermine the communist racial harmony and cause divisions in society to undermine the system of government, with this they can easily use the opportunity to implement the coup agenda. The role played by the Communist Party of Malaya (CPM) and 
Vol. 9, No. 2, 2020, E-ISSN: $2226-6348$ @ 2020 HRMARS

the triad is evocative of racism and prejudice, anxiety and frustration of the Malays in an atmosphere that is absolutely not clouded by mutual trust between the Malays and the Chinese (Jamaludin, 2011: 43). At the end of the post-election the Malays face increased variety of racial insults and threats to the future well-being and lives of their race in their own homeland (Ahmad, 2004: 13).

After the Tun Abdul Razak held the position of Director of Majlis Gerakan Negara (MAGERAN), he warned the public that some subversive or communist guerillas and supporters are planning to take advantage of unrest feeling and suspicious of interracial to cause chaos in the country, Some of them have been arrested and detained, but there are many more believed to be waiting for an opportunity to act. On 16 May 1969 the government arrested ninety of communist fanatics and supporters who are hiding.

"As you know under the Proclamation of the Emergency and under Emergency Essential Powers. Ordinance number 2, I have been given wide power to administer the country. However I would like to assure Fellows Malaysians that I wild use these powers fairly but with firmness that is necessary to restore law and order to this country as quickly as possibble. I shall do my best to see that the administrative machinery of the Government functions smoothly while at the same time the Government will continue to take firm and effective measures against those people who have shown disloyalty to this country and whose main objective in life is to destroy the peace and harmony that the people of this country of all races have enjoyed for so long" (Nik Anuar Nik Mahmud, 2000:7).

An action is immediately taken by the government by ordering Lieutenant Colonel Syed Hamzah bin Syed Abu Bakar to lead security operations to combat the riots occur and hinder the movement of the communist party. ${ }^{1}$ Given that public safety is an important aspect, the government took the best approach to conducting careful planning until security can be restored. This shows the efforts of the government in the process of bringing peace in the society and the state. The actions of the government in strengthening national security and defense aspects of the indirect cause of communist agenda to dominate the country hindered.

\section{After Riots May 13, 1969}

In the early 1970s the Communist threat is the most dominant faced by the government. The communists tried to do a variety of tactics and strategy of armed insurrection in their efforts to build a state of the Republic of Communists in Malaya. Although the security situation is emphasized, but this does not mean the threat from abroad does not exist at all against Malaysia. Malaysia should not look at issues of defense and security from one angle but also must see the threats coming from outside. Given the problems of defense and security are two

${ }^{1}$ Lieutenant Colonel Syed Hamzah bin Syed Abu Bakar is a Military Operations Commander Officer. View Nik Anuar Nik Mahmud, Muhammad Haji Salleh Abd. Ghapa Aaron. 2011. Biography Tun Abdul Razak: Statesman and Patriot. National University of Malaysia. 274 pp. 
Vol. 9, No. 2, 2020, E-ISSN: 2226-6348@ 2020 HRMARS

important elements stressed by the government, hence the financial budget allocated to these two things increased. In 1971, the safety aspect gained an increased budget from the previous RM813.2 million to RM875.1 million in 1972. In 1973 it was increased to RM1000.2 million, until 1976 spending increase security sector experienced an increase of RM1842.1 million. Overall, from 1971 to 1976, the government allocated a total of of RM7030.1 million for domestic security and defense.

The increase in the budget allocation for security sector on an annual basis starting from 1971 up to 1976 prove the seriousness of the government in fighting the communists in the country and the issue of security and national defense. The government is trying to strengthen Malaysia's security and defense systems, the strengthening of both of these aspects are properly and systematically implemented to strengthen defense and security aspects at the same time avoid the invasion of communist and May 13, 1969 riots did not recur (Hassan, 2003: 45-46). The following table shows information related budgetary aspects of defense and security in the country.

Table 1 Malaysian Government Security Budget Estimate (Domestic Security and Defense from 1971 to 1976).

\begin{tabular}{|c|c|c|c|c|}
\hline Years & $\begin{array}{c}\text { Internal } \\
\text { Security } \\
\text { (Million) }\end{array}$ & $\begin{array}{c}\text { Defender } \\
\text { (Million) }\end{array}$ & $\begin{array}{c}\text { Security } \\
\text { (Million) }\end{array}$ & $\begin{array}{c}\text { Percentage } \\
\text { (\%) }\end{array}$ \\
\hline 1971 & 245.5 & 267.7 & 813.2 & 11.58 \\
\hline 1972 & 284.2 & 590.9 & 875.1 & 12.45 \\
\hline 1973 & 319.2 & 681 & 1000.2 & 14.23 \\
\hline 1974 & 345.1 & 747.1 & 1092.2 & 15.54 \\
\hline 1975 & 388.4 & 1018.9 & 1407.3 & 20 \\
\hline 1976 & 570.9 & 1271.2 & 1842.1 & 26.20 \\
\hline Total & 2153.5 & 4876.8 & 7030.1 & 100 \\
\hline
\end{tabular}

Source: 1971-1976 Budget Estimate, Treasury of Malaysia 
Figure 1 Malaysian Government Security Estimate Budget (Domestic Security and Defense from 1971 to 1976)

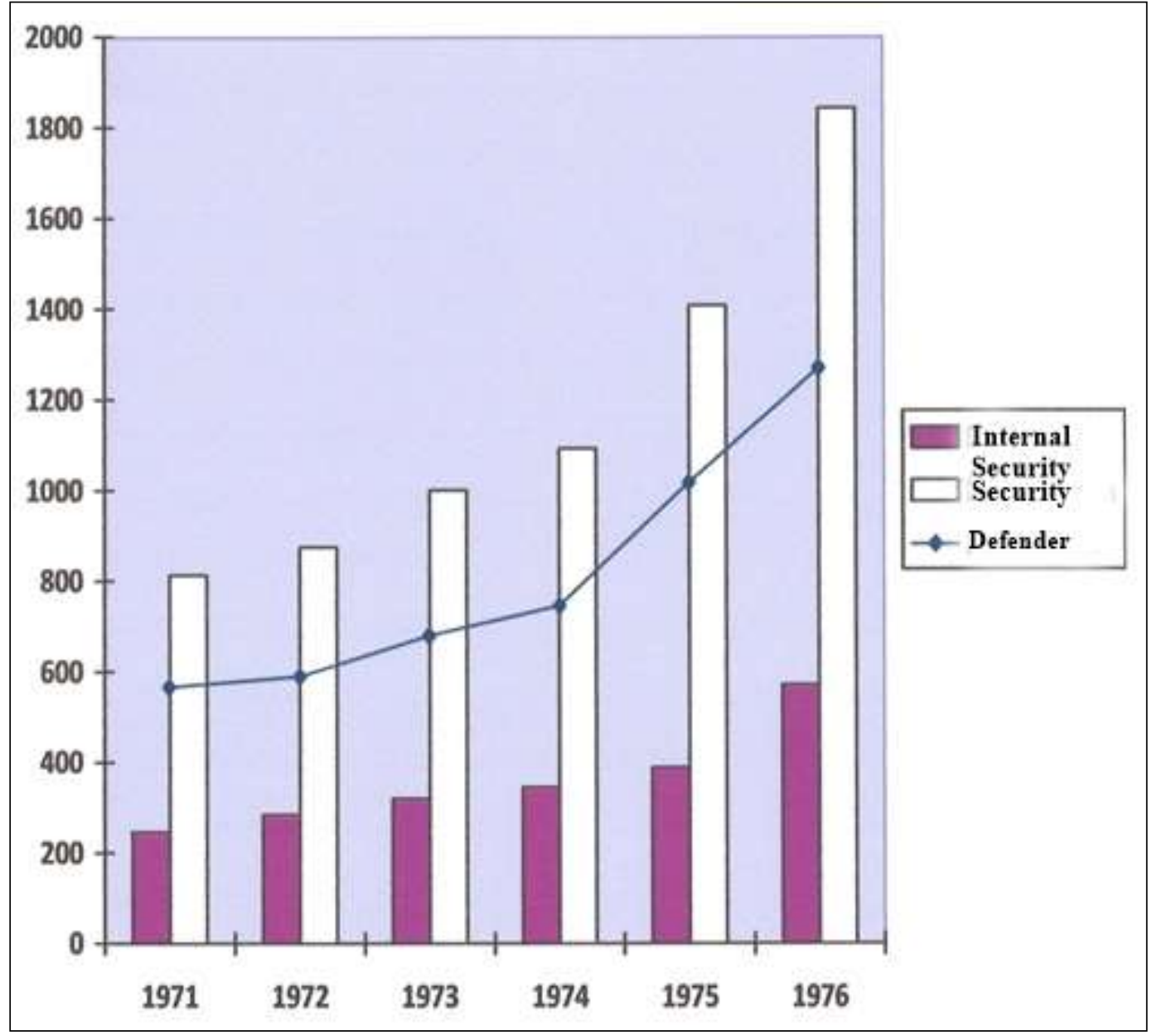

Source: 1971-1976 Budget Estimate, Treasury of Malaysia.

Although several large areas in the Federation of Malaya is free from the dangers of communism and the remnants of the communist group will be destroyed, unfortunately this does not hinder the communists' plan to take over the government and establish a communist state in the country. ${ }^{2}$ As part of the new communists' plan, violence is no longer used instead they were using betrayal which is are far greater dangerous. It is the responsibility of the security forces and the government in order to determine the motion was dismissed.

2 Director Lu Ting-yi of the Communist Party of China (CPC) Central Committee made an important speech. Lu Ting-yi said that journalism is a weapon for the struggle of life. Legislative news New China News Agency is a weapon for the struggle of living levels as well as with the Government, the Armed Forces, the Court, newspapers and schools are the weapons used to build socialism. See Government White Paper. Communist threat to the Federation of Malaya. Volume 1. No.23. Kuala Lumpur: Government Restructuring Office. 1959. p. 13. 
The government's strategy in the face of the communist threat is through three sectors simultaneously, namely to intensify security measures, develop the economic sector and strengthen solidarity in society. Up to now, the threat of communist insurgency is blocked successfully by the government the fight against the communists will not succeed if only to rely solely on the armed forces alone. The real fight is to achieve lasting peace in the field of social and economic progress. Only people who are united and fair can be a fortress to prevent communist subversion (Government White Paper, 1959: 1).

Figure 2 Government's Strategy to Face the threat of Communist in the Country

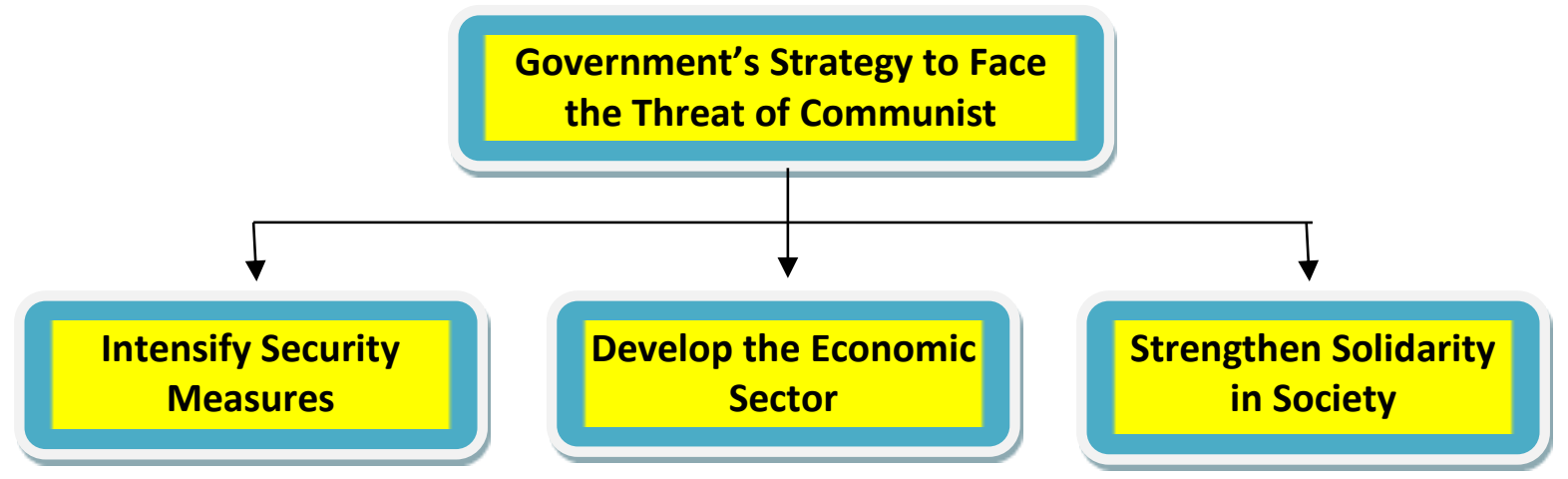

Source: Adapted from the Government White Paper: Communist threat to the Federation of Malaya. Volume 1. No. 23. Kuala Lumpur: Government Restructuring Office. 1959.

Simultaneously with the security measures, the government in the Second Malaysia Plan also launched economic and social measures to accelerate investment and economic development with national unity and prosperity as the goal. Malaysians from all walks of life can definitely look forward to a more secure and full opportunity to live in a prosperous and united society. It is been the pledge of the Government to strengthening the country's defense system from time to time and to eradicate the threat of communism is an agenda as well as the government's efforts to bring peace, unity and national security.

\section{Overview}

The Government has done a lot of effort to prevent and paralyze the activities of the communists and among them is by working with the police to get intel information and to take action in terms of controls and raids on subversive group to ensure safety in the country. All the measures taken can be regarded as a concerted effort by the government to curb the influence of communists and as soon as the issue of race relations as a result of riots that broke out May 13, 1969. Food supplies from outside restricted from entering these states as the government try to prevent communist from taking advantage of the riots, which aimed to seize power and cause chaos in the country. In this way indirectly inhibit activity and communist movement. As a result, security forces can arrest ninety members and supporters of communist riots until May 16, 1969. The government managed to break the insurgency and the threat of communism in the country.

Hence, in order to eradicate the communist elements and restore peace, some action has been taken. The government acted to revive Village Control Team which was established during 
the era of confrontation. Hundreds of members were taken to serve in this force that seeks to control residential areas, government buildings and public interest. In addition, the government also focused on combating the evil elements like secret societies, such as monitoring the activities of members of the Labor Party which had sparked tension before. In June 1969, a total of 7,000 people were arrested for various offenses. The government security forces expands its influence by adding three more army battalions and a battalion of local teams, including five police forces forest. These additional security forces are expected to be able to control the security and restoring peace.

The polling day for both the parliamentary elections and the state election in Peninsular Malaysia falls on a Saturday, that is on 10 May 1969. This is worrying because the previous experience of the funeral events in Kepong, the security forces responsible for guarding the country and maintain security in the country concerned if it happens again that more protests and possible attempts to disrupt the elections, especially the area near the capital. The police and security forces were on alert. After examining the police report on internal security, the government found no signs of unrest and the communist movement and activities taking place in the country other than in Selangor and Malacca

Thus, the government instructed the police force to not only to carry out raids in the country but also to examine closely every person who wants to leave Johor to Singapore to ascertain that none of them were armed, or known as a communist stooge. This measure is effective and able to break the communist element and no more riots on the island. Curfews were also enforced led to the negative affect to country's economy. Therefore the government feels it is necessary so that the curfew time is reduced as to an that the safety of the civilians is ensured. In mid-June, a curfew was conducted in all regions except in an area in Kedah near the Thai border. Such thing is due to the fact that the region's armed communist guerrillas are still active, therefore is reduced to only a few hours a day and apply between the morning until four in the morning.

\section{Conclusion}

In reality the government is aware of the role and involvement of the communist era during the occurrence of riots on May 13, 1969. The riots on May 13, 1969 not only sparked by racial sentiments raised by the Chinese and Indians but also the role played by the communists. The role of the communist party is also important in triggering riots at the time. Even the communists using propaganda to the public in an attempt to blow out the fire of racism that racial tension and chaos in society. In this way it makes it easier to implement a communist agenda in creating a communist state in the region. The Chinese Communist Party and the Chinese political party were the ones who carry out this agenda. During the riots, the communist had been seen to be using the likes of Chinese and the Labor Party to create chaos. Such tactics used by communists in his plans to conquer the country. Chinese political parties and leftist parties viewed very useful by the communists in implementing any plans. Before the riots, the government under the administration of Tunku Abdul Rahman is also facing the same situation, namely the uprising of 
the communists. Rebellion after rebellion carried out by the communists but were prevented by the security forces and the army.

To sum it up, the government had been taking precautionary measures from time to time and try to prevent the existence and movements and communist influence in the interethnic riots. Various efforts taken by the government in removing the communist element such as intensifying security measures and increase the budget allocation for the national security sector. Using the power of salvation and planning, communist influence gradually be broken. Steps taken by the government with sanctions, inspections at the border, curfew, declared an emergency and so cause the communists quite difficult to expand the influence and at the same time limiting the movements and plans.

\section{Corresponding Author}

Mohamad Asrol Arpidi Mamat, PhD student at Department of History, Faculty of Humanities, Sultan Idris Education University, 35900 Tanjung Malim, Perak.

Email: r_pd85@yahoo.com

\section{Reference}

Ahmad, A. (1985). Tengku Abdul Rahman and Malaysia's Foreign Policy 1963-1970. Kuala Lumpur: Berita Publishing Sdn. Bhd.

Ibrahim, A. R. (2006). May 13, 1969: Black History Contact Malays and Chinese in Kuala Lumpur. Kuala Lumpur: Universiti Malaya.

Constitution. (2003). Kuala Lumpur: Government Printing Department.

Faith, H., \& President Soekarno. (1964). The Army and the Communist: Changing the Triangle Shapes in ASEAN Survey. August 1964. IV (8).

Kua, K. S. (2003). Tunku memories. Petaling Jaya: Strategic Information Research Development (IRD).

Kua, K. S. (2007). May 13: Declassification of Documents about Riots 1969 Malaysia. Selangor: Suaram Communications.

Comber, L. (1983). 13 May 1969: A Historical Survey of Sino-Malay relations. Kuala Lumpur: Heinemann Asia.

Esa, M. S. (2011). Tun Abdul Razak's Role in Administration and National Development. Kuala Lumpur: Universiti Malaya.

Mahmud, N. A. N. (n.d.). Tun Razak, May 13 tragedy and National Unity. Kuala Lumpur: National Archives.

Mahmud, N. A. N. (2000). The tragedy of May 13, 1969: Hidden Blessings. Kuala Lumpur: National Archives.

Omar, N. A. (2006). Events Communist in Kedah Under the emergency, 1948- 1960. Kuala Lumpur: Universiti Malaya.

Samad, P. A. (1998). Tun Abdul Razak: A Phenomenon in Malaysian Politics, A Political Biography. Kuala Lumpur: Affluent Master Sdn. Bhd.

Report of the National Operations Council. (1969). The tragedy of 13th May. Kuala Lumpur: Youth. 
INTERNATIONAL JOURNAL OF ACADEMIC RESEARCH IN PROGRESSIVE EDUCATION AND

DEVELOPMENT

Vol. 9, No. 2, 2020, E-ISSN: 2226-6348 @ 2020 HRMARS

Jamaludin, R. (2011). Emergency in Sub-District Sungai Siput Utara, Perak, 1948-1960. Kuala Lumpur: Universiti Malaya.

Speech by the Prime Minister and Chairman of the Council of National Unity, the First Meeting of National Unity Council, at the Dewan Tunku Abdul Rahman on July 1, 1971.

Kooi, T. P. (2000/2001). Leadership Tun Dr. Lim Chong Eu in Penang Until 1974 Kuala Lumpur: Universiti Malaya.

Shaw, W. (1977). Razak: CVs and His time. Kuala Lumpur: Longman Malaysia Sdn. Limited.

World Encyclopedia. (2005). Kuala Lumpur. Dewan Bahasa dan Pustaka. 